Behind the Scenes of Al-Qa ida’s Media StrategyAuthor(s): Agnes Hankiss

Source: Journal of Strategic Security, Vol. 12, No. 2 (2019), pp. 60-76

Published by: University of South Florida Board of Trustees

Stable URL: https://www.jstor.org/stable/10.2307/26696260

JSTOR is a not-for-profit service that helps scholars, researchers, and students discover, use, and build upon a wide range of content in a trusted digital archive. We use information technology and tools to increase productivity and facilitate new forms of scholarship. For more information about JSTOR, please contact support@jstor.org.

Your use of the JSTOR archive indicates your acceptance of the Terms \& Conditions of Use, available at https://about.jstor.org/terms 


\title{
Behind the Scenes of Al-Qa'ida's Media Strategy
}

\author{
Agnes Hankiss Dr \\ National University of Public Service, Budapest, agneshankiss@gmail.com
}

Follow this and additional works at: https://scholarcommons.usf.edu/jss pp. $60-76$

\section{Recommended Citation}

Hankiss, Agnes Dr. "Behind the Scenes of Al-Qa'ida's Media Strategy." Journal of Strategic Security 12, no. 2 (2019): : 60-76.

DOI: https://doi.org/10.5038/1944-0472.12.2.1714

Available at: https://scholarcommons.usf.edu/jss/vol12/iss2/4 


\title{
Behind the Scenes of Al-Qa`ida's Media Strategy
}

\section{Author Biography}

Dr. Agnes Hankiss is a psychologist, writer, honorary professor and head of the Counterterrorism Department of the National Security Institute at the National University of Public Service. She is the founder and director of the Hamvas Institute for Cultural and Security Studies at Budapest, which, in its research and publications in the last 17 years, has been focusing on the functioning of the communist State Security services. She was a member of the European Parliament (2009-2014) as a representative of the EPP, Vice-Chair, Committee on Petitions, Member of the Committee on Internal and Legal Affairs, Member of the Subcommittee on Security and Defense, Member of Special Committee on Organized Crime, and Member of the Interparliamentary Delegations for Relations with the US and Israel. Her main fields of work in the EP were the Internal Security Strategy of the EU, Terrorism and Counterterrorism, the EU's CBRN action plan, and Cyber Security.

\begin{abstract}
Jihadi terrorist organizations view their media opportunities as weapons in their war against the West. While there is a considerable body of work discussing the content and form of AlQa'ida's media, including both their written press and video products, we have significantly less information on what goes on behind the scenes: how the tactical elements and strategic goals are designed and implemented to generate these products. The paper asserts that while we still have insufficient information on the media strategies of the Islamic State, due to the ideological, operational and network-to-network continuity between the two organizations, the documents shedding a light on Al-Qa'ida's press efforts can serve as valuable resources in understanding present-day (and maybe the future of) jihadi media as well.
\end{abstract}

This article is available in Journal of Strategic Security: https://scholarcommons.usf.edu/jss/ vol12/iss $2 / 4$ 


\section{Introduction}

After analyzing the networks behind the brutal terrorist attacks that have taken place in Europe in recent years, it seems conclusive that the guidelines published in jihadi media, in these cases, tools for psychological warfare aimed at disseminating fear and confusing counterterrorist efforts-relayed to the target audience via planned media messages and social platforms. ${ }^{1}$ At this time, however, it is challenging to uncover the strategic purposes and tactical considerations underlying the media activity of the Islamic State. That is why, even though they are from a period preceding the declaration of the Islamic State, the 17 emails found during the raid on Osama bin Laden's house in Abbottabad-and later made available for research purposes by the West Point Counter Terrorism Center (CTC) - invaluable source material. The letters, written partly by bin Laden, partly by various al-Qaida leaders to bin Laden, offer unique insight into the inner world of al-Qaida, as well as the media plans and thought processes of its leadership. This paper intends to provide a detailed analysis of these documents and assert that the ideological and network-to-network continuity between al-Qaida and the Islamic State renders analyzing the media strategies of the former a fruitful endeavor towards understanding the present-day media practices of the latter.

A different set of documents from Iraq, also made public through the West Point CTC Harmony Program, provide further interesting details on these strategic considerations and media control operations. While these files originate from the decade after 9/11, they may-based on ideological and strategic continuity between such organizations-serve as a foundation for revealing the propaganda machine and soft underbelly of today's highly active terrorist groups as well. Daniel Milton's work on the media efforts of the Islamic State likewise "attempts to examine declassified documents captured from the group's predecessors to provide a baseline understanding of its present-day media structure and operations."2

As the following section will discuss, there is a vast body of evidence indicating strong ties between al-Qaida and the Islamic State. Such an example for a bridge between past and present could be al-Qaida leader Ayman al-Zawahiri, who frequently appears in the aforementioned documents: He called for the latest jihad against the US and Europe in May 2018. The diversifying process following the Islamic State's loss of territories and influence may lead to an amalgamation of the remaining al-Qaida and Islamic State forces. There are alternative theories that this may occur under the leadership of Hamza bin 
Laden, as al-Zawahiri has been considered a traitor and rejected as a leader by many. As to why al-Qaida members and leaders are suspicious of al-Zawahiri, Ali Soufan mentions a rather enigmatic episode of his life in his book, Anatomy of Terror. Soufan reveals the complexity of networks and spheres of interest at play: At the end of 1996, al-Zawahiri, a veteran of the Afghan jihad, who had also fought alongside both bin Laden and Sheikh Rahman, traveled to Azerbaijan. From there, he entered Russia in a small van, carrying 6400 USD, accompanied by two operatives of the local cell of his organization (the Egyptian Islamic Jihad) and a Chechen fixer. They pretended to be merchants, but since they had no personal documents, the Russian security services stopped them. He was sentenced to six months, but he was released after five with time served. He returned to Afghanistan and managed to contact the members of the Chechen jihad. There is no further information regarding any potential breakthroughs that the Russian services may have had with him, and the court's leniency remains likewise unexplained. The relevant facts may be hidden somewhere in Russian documents. 3

\section{Continuity Between al-Qaida and the Islamic State}

While this may not be common knowledge, the perpetrators of the recent European attacks had complex personal relations with major European alQaida figures who provided them with considerable ideological and logistical support. While the majority of these attacks are attributed to the Islamic State, many of the assailants often collaborated on preparing these atrocities with alQaida members. The perpetrators of the Paris and Brussels attacks with the strongest ties to veteran al-Qaida fighters, ideologists, and recruiters also played a key role in the Francophone network of the Islamic State. Such connections, sometimes spanning as long as decades, are also identifiable in the case of radical cells and communities in Germany and the UK.4

Following are a few typical examples. Abdelhamid Abaaoud, the ringleader of the European attacks; Najim Laachroui, architect and bomb maker of the Paris massacre and suicide bomber of the Brussels Airport; as well as Chakib Akrouh, the Saint-Denis suicide bomber, had all been in close contact with Khalid Zerkani, a radical veteran of the Afghan jihad long before the Paris and Brussels assaults. Members of Zerkani's cell had met each other in al-Qaida training camps in Afghanistan and the group's operative cells in North Africa.

After they participated in terrorist attacks in 1999 and the early 2000s, they had a significant role - one and a half decades later - in radicalizing and 
recruiting a generation with strong ties to the Islamic State - the generation of the Paris and Brussels terrorists, for instance. Zerkani used Turkish human traffickers to transport foreign fighters to Syria, for which he was arrested in February 2014. The Molenbeek district in Brussels also hosted Fatima Aberkan, who joined the jihadi movement in 2007. She operated a recruiting and travel network until her 2015 arrest. Within the network, she was known as "the Mother of Jihad.” Her brother was convicted in 2003 for participating in the assassination of Iraqi military leader Massoud. Salah Abdeslam - the logistics coordinator of the Paris attacks - had family ties to the Aberkan family.

Another person of interest with Moroccan background, Molenbeek resident Gelel Attar from Zerkani's circle, travelled to Syria with Akrouh in 2012 (for the first time). The main suspect of the thwarted 2016 Paris attack, Reda Kriket, financier of the Zerkani cell, also had strong ties to Akrouh and Abaaoud. Yoni Patrick Mayne, also from Zerkani's network, travelled to Syria in January 2014 with Abaaoud. Charlie Hebdo attacker Cherif Kouachi and Amedy Coulibaly, the perpetrator of a deadly assault on a Paris supermarket, were collaborating with al-Qaida Salim Benghalem, the other ringleader of the European attacks, on the preparations for breaking a jihadi extremist out of prison as early as $\mathbf{2 0 1 0}$ - years before the terrorist attacks in Paris.

In 2011, the two accompanied Benghalem to Yemen, where they served beside al-Qaida commander Anwar al-Awlaki. Kouachi and Coulibaly were also preparing for an operation with Djamel Beghal, who had been one of the key figures of al-Qaida in Europe as well as the organization's contact person to fundamentalist groups in Britain from 1997. He was also responsible for the 2001 attack against the US Embassy in Paris. (Together with 450 other radicals, Beghal will be released from French prisons by 2019.5)

In Aleppo, Salim Benghalem tortured and executed Western prisoners with Mehdi Nemmouche, who attacked the Brussels Jewish Museum years later, in May 2014. Islamist veteran Fabien Clain was arrested in 2009 for preparing an assault on the Bataclan theatre: He may have been responsible for choosing it as a target six years later. Fabian Clain worked together with Abaaoud at the external operations command in Raqqa. Yet another example for these overlapping networks is one of the perpetrators and organizers of the 2017 Barcelona attacks, Abdelbaki Es Satty, who established close contact with Moroccan al-Qaida fighter Rachid Aglif, one of the 2004 Madrid train 
bombers, in prison in 2012, and stayed in Belgium (in Molenbeek) for months in 2016.6

These overlapping networks and ties between al-Qaida and the Islamic State survived the infighting and differences in character between the two organizations. Similarly, in a recent presentation, Brian Fishman proposed, "starting the clock" on the Islamic State in October 2006 instead of the more commonly cited 2014.7 The continuity is also noticeable in the structural similarities between the networks of al-Qaida and the Islamic State, while for example - the international network run by Carlos in the 1970s and 80 s from Budapest shows marked differences from both. ${ }^{8}$

\section{Behind the Scenes: Al-Qaida Media Strategies}

There is a wealth of studies enumerating jihadi media forums, analyzing the text and visual content of various jihadi media platforms (such as Inspire, Dabiq, or Rumijah) and discussing their goals (such as propaganda, recruitment, intimidation, or training). Meanwhile, we know significantly less about the process, concept, and internal logic of planning and creating that media. Daniel Milton's observation about this discourse, that it "mainly relies on what the group creates for external publication" and it "has been unable to answer questions regarding the structure, policies, and management of the group's media arm,"9 rings just as true for the media efforts of al-Qaida as it does for those of the Islamic State.

The endeavor to uncover such al-Qaida media strategies found valuable - if not entirely exhaustive - resources in the documents discovered in bin Laden's Abbottabad safe house. These letters have undergone primary analysis at the hands of West Point CTC experts - from aspects different from the one that this study will attempt to present. Their work resulted in papers such as Liam Collins's discussion of bin Laden's security measures ${ }^{10}$ or a comprehensive study by N. Lahoud et al. of the letters in terms of how they illustrate the conflicts between bin Laden and the regional al-Qaida branches and the leadership's attitude towards the events of the Arab Spring. ${ }^{11}$ Their observations also bear relevance to the analysis of media strategies. Yet examining the letters through this particular lens may shed further light on alQaida media operations.

It is clear that bin Laden wanted centralized media above all: Not only because he saw a coherent and authentic media strategy as a key weapon in the fight 
against the West, but also because he thought that keeping all branches of the media in one hand might help rein in the splinter groups that were fighting on their own. As Lahoud et al. point out,

“Bin Laden was not even inspired by Inspire, AQAP's [al-Qaida in the Arabian Peninsula] English-language magazine designed to appeal to Muslim Americans to launch random attacks in the United States (...) In view of the recent marketing of 'lone wolf' operations as 'New Age' jihad, bin Laden instead urged methodical planning of suicide operations." 12

Naturally, the integration of media strategy into the greater scheme of political strategy restricts the options for practical and tactical considerations. In a letter to "Shaykh Mahmoud" (Atiyyah Abd Al-Rahman), bin Laden presents the main directives as "expanding the programmed and directed media, and our efforts in directing the nation's research and deciding on a specific plan that we all discuss." He notes that:

"the oncoming stage is important and very dangerous and does not tolerate the apparent differences in our directives, [adding,] due to our efforts in plugging that gap and preparing a plan to guide the nation, we must mobilize all the resources that have expressive abilities in speech, poetry, visual, or audio and devote them completely toward directing and guiding the nation's youth."13

Another letter, written to AQAP leader Nasir al-Wuhayshi (or “Abu Basir”) by an unidentified author (according to the CTC, the most likely candidates are Osama bin Laden and/or Atiyyah), uses a rather vivid metaphor to summarize its strategic concept:

"The enemy can also be described as a wicked tree. The trunk of that tree is $50 \mathrm{~cm}$ wide. The tree has many branches, which vary in length and size. The trunk of the tree represents America. The branches of the tree represent countries, like NATO members, and countries in the Arab World. We, on the other hand, represent a person who wants to cut down that tree. Our abilities and resources, however, are limited, thus we cannot do the job quickly enough. The only option we are left with is to slowly cut that tree down by using a saw....We want to saw the trunk until the wicked tree is down. God willing, once the tree is down, 
its branches will die thereof...Their tree fell down, then its branches died out, from South Yemen to Eastern Europe."14

Atiyyah Abd Al-Rahman was a veteran jihadi who, while not bearing any official rank or status, gained his influence in the organization from being a close friend and confidant to bin Laden. He joined al-Qaida in 2007 as a member of the Lybian Islamic Fighting Group and fielded a small, ragtag private army in Waziristan. He was bin Laden's main contact to various branches, distant fighting factions and the operations center. Ten years after 9/11, bin Laden still entrusted him with choosing the operatives and their coordinator for a planned terrorist attack on the United States, asking him to "nominate a qualified brother to be in charge of a large operation in America." $15 \mathrm{He}$ also relied on Atiyyah in recruitment decisions, requesting "the résumé of all the brothers who might be nominated for high administrative positions now or in the future." 16

What is noticeable and remarkable at first sight is how the majority of these letters - unlike the hate-filled articles and brutal videos aimed at the "general public" - discuss, in practical and unemotional terms, the "force fields" of effect and counter effect, and the enemy's foreseeable response to each planned press release. As the letter on al-Qaida strategy warns, "All public announcements must be carefully evaluated. When issuing a public announcement, ask the question of what sort of positive or negative impact this announcement will generate for us?"17

Behind the spectacular and revolting scenes, the organization's media activity-its content, message, and tools - were meticulously and professionally planned. To illustrate this, in a letter discussing media strategy, American-born al-Qaida spokesperson Adam Gadahn openly and lengthily criticizes "Shaykh Ayman" (al-Zawahiri) for a statement directed at the US, where the Shaykh refers to Benjamin Franklin as "a previous president of yours." Gadahn further explains,

"We should remind that (Benjamin Franklin) was not a president, but a 'statesman'...I do not know the source of the story, or its popularity amongst the Americans. But such a mistake may be used to slander the Shaykh and accuse him of talking about something he does not master (politics).....Although plenty of the Americans may also think that (Franklin) a president...but this mistake is not usually committed by 
those talking in politics, analyzing and discussing. It is a common mistake among general people and not between specialists." 18

The media coordinators also paid special attention to timing these media appearances. Bin Laden considered miscalculated propaganda timing a mistake and a sign of amateurism. "It is extremely important to pay close attention to timing," an unidentified strategist wrote. "Timing is everything. This saying has been proven to be true now and then." 19 On one occasion, bin Laden sharply criticized a coordinator for publishing a press communiqué demanding the release of a jihadi prisoner incarcerated for financing terrorism. While he agreed with the content, he considered the timing counterproductive: As the issuing of the press communique coincided with the Gaza flotilla raid, it had the potential for distracting readers from the Palestinian operation against Israel.

\section{Al-Qaida's Efforts to Create a Centralized Media}

In 2002, the first issue of the Characteristics of Jihad Magazine is published. Al-Zawahiri sets the tone in his introduction. "This magazine is being published during a time when there is a worldwide conspiracy against Jihad," he writes. The first issue covers three main areas of interest: Religious topics, the proper rituals surrounding suicide bombings, and questions of morality and behavior. The magazine is accompanied by a cover letter, in which the author, the editor-in-chief of the quarterly, expresses his hopes that the recipient, Abu-Muhammad will write the editorial and support the publication both financially and content-wise. He requests, "the names of the authors so that we may use the same names in future articles." 20 It is clear, however, that the editor doubts his own judgement regarding the articles and - probably wary of the consequences of a possible mistake - suggests setting up a censorship body, a "religious committee" of sorts. The strategic purposes of launching the magazine are also clearly defined: "Regarding the platform of the group," the editor explains, "until now and as far as we know, the group has no clear platform through which it can be recognized by the people." ${ }^{21} \mathrm{He}$ adds that:

"there is no consensus with regards the [group's] publications; on the contrary, there is much criticism of those publications. We need a clear platform that communicates to the people the group's positions with regards to belief and ideology. We need this platform so that the members of the group may agree on rules that everyone must follow, or 
at least rules that can be adopted by the group....Had we heeded their call then, we would have been close to completing this task by now. I'd like to remind [you] of something that I have mentioned in the past: even if it is a long-term goal, working to establish a religious committee is a very important matter that helps us avoid becoming victims of an individual's changes in opinions. In order to avoid any disagreement, it is possible to have Islamic scholars review any platform we write.”22

In 2006, however, the practice of such improvised solutions and individual projects came to a halt. In autumn, al-Zarqawi and the leadership of AQI (AlQaida in Iraq) established a center supervising all media activities, the AlFurqan Institute for Media Production, which miraculously survived every reorganization and diversification effort, and eventually even produced propaganda material - including execution and beheading videos - for the Islamic State. Abu Muhammad al-Furqan became the first minister of information and a key media coordinator for the IS until he was killed by an air raid on 7 September 2016 in Raqqa.

From 2006, the Institute was hard at work on setting up an operational model. "It has to be said that media has a big effect on managing a war, it is one of those weapons that we cannot do without during the war against the Crusaders," a letter from the Al-Furqan Media asserts. ${ }^{23}$ "Nowadays, everyone is aware of the media importance, so in order not to repeat the same mistakes of the past, we have decided to set up this structure to institute a media process in the state," boasts a March 2007 document, which the author, supposedly mesmerized by organized propaganda, introduced with a poem about the importance of media (unfortunately missing from the English translation). ${ }^{24}$

This great enthusiasm also shows in how, under the umbrella of centralized coordination, a bout of diversification commences: Publishers, magazines, and websites proliferate at an unprecedented rate. In his study, Philip Seib lists the freshly launched or refurbished media outlets. 25 By 2008, al-Qaida was running 4000 websites. The group's production company, As-Sahab, set up in 1988 by bin Laden, released 16 videos in 2005, 58 in 2006 and more than 90 in 2007; all the while monitoring - not unlike a Hollywood studio what the audience may find appealing. The so-called "Jihad Academy" incited fighters with images of attacks and suicide bombings. Even Al-Zarqawi made a propaganda video of himself personally beheading US businessman Nicholas Berg in 2004 in Iraq. The video was downloaded half a million times in a 
single day. Another online magazine, Camp of the Sword focused mainly on training fighters, claiming that their self-study program - including intelligence gathering and wiretapping techniques - required no boot camp visit.

\section{Internal Rules for Introducing Suicide Bombers}

Jihadi media strategists also designed a "script" for presenting suicide bombings. Formally, they suggest that "the will reading should be about 5-7 minutes long" and that "the uniform should be black clothes and there should be no background and they should have plenty of weapons beside them." They advise the person filming "the suicide brother" to be aware of the following:

"The chosen words relayed to our suicide brothers, whether it is advice or similar should be kind words. But we have seen that some need direction and we are accused of being warriors and not respecting scholars as we think that we are highly intellectual and superior compared to others and we have been descried by many as rude. Regardless of whether we have been misjudged - we plead our case to God-we are not going to question our virtuous brothers - but our duty is not to hallow these thoughts but to concentrate on compassionate words.... When you are taking pictures of a martyr, please adhere to the following: Pay close attention to most of the words chosen by the martyr brothers about guardianship etc. and make sure they say good things, but we have seen some where they are not paying attention and they need direction because we are being accused of being mujahidin by not honoring the leaders and we are accused of spreading religious persecution and acting superior to the people and we are described as alienating and described as having bad morals and no doubt overlooking the extent of that for our injustice - May God take care of the Complainers - we do not doubt the words of the pure brothers - we heed them and god heeds them - our duty is not to ignore these suspicions"

The text, although in places slightly confusing, is remarkable because-instead of the suicide bombers, whose mental and psychological state has been thoroughly analyzed-it provides insight into the mentality of the person behind the bomber: The one who, despite considering the attack a sacred mission, orders someone else to carry it out. Suicide attackers tended to be outsiders, foreign fighters, not members of the AQI or the ISI top brass. This 
must have struck much of the target audience (of mobilize Muslims) as dishonorable and thus forced jihadi media to rhetorically challenge the widely held belief that their leaders consider themselves superior and heartlessly send suicide bombers to their death.

Another document presents an entire "scenario" of recommendations: Specific content to be included in the videos introducing the suicide bombers (each point complemented with the phrase "May God rest his soul"). The recommended talking points include questions such as "Introductions to his life-May God rest his soul-his upbringings and mentions of his quality. The beginning of his Jihad where and when?" or "How did he organize the attack group before and after the fall of the regime?" and "The pledge to Sheik Usama and how did you announce it." 26

On 10 December 2009, there was a session of the High Command for Jihad and Liberation Media and Recruitment Department with representatives from various governorates' "media platoons." The "top secret” minutes of the longwinded, meticulous committee meeting provide detailed insight into the flow of conversation. The attendees took their time to mull over issues such as media work related security measures, risks of using email and mobile, or the details of work coordination. Their primary mission was clarified by a comment from Deputy Commander Doctor Kamal al-Din al-Naqshabandi, who asserts, "in the media field we still suffer and we still fall behind because of media blockades imposed against us. Because of that we must build a media base....First to official and public national media...and then worldwide media outlets." 27

\section{Media Campaign on the $10^{\text {th }}$ Anniversary of 9/11: Centralized Media at Work}

Some letters found in Abbottabad deserve particularly thorough analysis given that the highlighted strategic and tactical dilemmas and considerations have far-reaching implications. In his 10 October 2010 letter to Shaykh Mahmoud, bin Laden outlines his ideas concerning the anniversary. His observations and suggestions are answered a few months later in a letter to an unknown recipient by California-born al-Qaida spokesman Adam Gadahn.

"We need to benefit from this event and get our messages to the Muslims and celebrate the victory that they achieved," bin Laden observes about the political goal of the campaign. "We need to restore their confidence in their 
nation and motivate them. We should also present our just cause to the world, especially to the European people." ${ }^{8}$ In his analysis, the timing of the propaganda is fortuitous with regard to the grand scheme of politics. "Anyone who looks at the enemies in NATO, especially America, will know that they are in big trouble," he observes.

“This year has been the worst year for them in Afghanistan since they invaded it. The number of their dead has never been this high according to their own reports. Their financial crisis continues. Britain has lowered $\mathrm{i}[\mathrm{t}] \mathrm{s}$ defense budget and America is reducing the budget of the Pentagon. Anyone who knows the world and knows politics, knows that it is impossible for them to continue with the war. There is no difference between them and the Soviet Union before it withdrew from Afghanistan."29

Yet, it is Adam Gadahn who transforms bin Laden's concept of the campaign into strategy and elaborates the details. "As for the benefit of exposing the Shaykh at this stage, we should look at this matter from all angles," he emphasizes, since bin Laden has not made a large-scale media appearance for almost ten years at this point. $3^{\circ}$ Gadahn finds "the 10th anniversary of the attacks of Manhattan and Washington" (or, as he also calls it, the "Manhattan battle”) a suitable occasion.

"Every exposure of him," he adds, "as long as it is not daily or semiweekly, should have an influence. The repetition of his exposure, irrespective of the vicious campaign that is waged against al-Qaida, everywhere, is by itself something that attracts attention." ${ }^{1}$

He also believes that the timing is especially suitable, because the US is preoccupied with economic hardships. As he points out,

"[at] the press conference held by Obama after the midterm elections, all the questions were on the bad economy, and the means to get out of the crisis. Nevertheless, not one of the journalists dared to embarrass Obama by questioning him about the influence on the American budget and the national economy of spending the billions yearly on the two wars of Afghanistan and Iraq." 32 


\section{Finding Channels and Contacts for al-Qaida's Messages}

In his letter, bin Laden also wonders which forums and channels would be suitable for broadcasting the planned al-Qaida media appearances. He seeks suggestions and explains his selection criteria.

"We should also look for an American channel that can be close to being unbiased," he writes, "such as CBS, or other channel that has political motives that make it interested in broadcasting the point of view of al-Mujahidin.”

He also suggests enlisting the journalists, some of whom are reliable supporters of al-Qaida, noting that the recipient

"should write to 'Abd-al-Bari 'Atwan and Robert Fisk and tell them that the tenth anniversary is coming and it is the harvest of a fierce war between al-Mujahidin and America. This is a chance to explain our motives for continuing the war....Tell them that we suggest that they make a documentary on this anniversary and we will provide them with printed, audio, and video materials." Bin Laden's peculiar connection to these journalists becomes clear when he advises his followers to "have them give us their video material and the names of specialists that they will use in order for us to establish a vision for the film and to be able to clarify the events."

In response to bin Laden's proposition, Gadahn asserts that there is no real difference between American television channels and other media outlets in terms of professionalism or bias. Nevertheless, he reviews the options. He excludes Fox News as the least professional and most biased broadcaster, writing, "let her die in her anger." He believes that although CNN closely cooperates with the government, the Arabic version of the channel provides detailed reporting with faithful quotations. He complains about less biased MSNBC firing its two journalists for controversial statements. "ABC channel is all right," he writes, "actually it could be one of the best channels, as far as we are concerned." They - especially terrorism specialist Brian Ross - are interested in al-Qaida, and they are proud of their interviews that they had made with the Shaykh. "It also broadcasted excerpts from a speech of mine on the fourth anniversary," Gadahn adds, "It also published most of that text on its site on the internet." 
Gadahn believes that the media department should distribute the material "to more than one channel, so that there will be healthy competition between the channels in broadcasting the material." His suggestions for the distribution method may also serve as a model for al-Qaida's general media strategy. He proposes that they send the material to 30-50 writers, experts, and independent journalists from various countries who are interested in al-Qaida and compiles the lengthy list of names. He, too, puts Robert Fisk at the head of the list.

"We would inform each," he explains, "that he has been chosen to be amongst a group of international journalists and writers, and that they will receive special media material on the tenth anniversary of 9/11.....There would be a password and a site address to download the materials at the right time, let it be 5 days before the anniversary, for example. This is easy -as I think- on our brothers working in the networking."

According to Gadahn, even if only one-third of the journalists show interest, "we would have 10 international journalists that will display our mission in the newspapers and channels. If the experiment works," he adds, "then I suggest to repeat it on every important occasion."

\section{Target Groups for the Campaign Messages}

Gadahn also specifies the target groups of the media campaign. He places special emphasis on the European nations, just as bin Laden did in his earlier messages. The media department would also like to address the entire Muslim world. The key strategic goal of shaking up and igniting the Muslim countries would soon be accomplished in the chaotic revolutions of the Arab Spring.

Jihadi forums, however, present Gadahn with an almost insurmountable problem, rendering winning the hearts of people - one of his key endeavorsa tough nut. Most of the Muslims find these forums "repulsive" or inaccessible. He believes that they "distort the face of al-Qaida, due to what you know of bigotry, the sharp tone that characterizes most of the participants in these forums."

Gadahn mentions a third target group. "We should also not forget the Mujahidin brothers in the fronts," he writes, "who are passing through crucial times and facing disaster after disaster." They, however, should be addressed 
through video messages, because "many people do not read, and even if they read, they are more influenced by visuals."

Visuality is also strongly featured in the documents from Iraq; for instance, in the above-mentioned minutes of the secret the Media and Recruitment Department meeting, where the participants instructed all their commanders:

"to document every Jihadist operations and said that it is unacceptable to the Supreme Commander to not take quality photographs of operations. And that a photographed operation is equal to 100 operations that were not photographed."

"The enemy of my enemy is my friend" is a common tactical element in hybrid warfare. Yet, in our modern era of "grey zones," the "enemy of my enemy" mechanism is no longer a safe point of reference in the intricate global system of asymmetric warfare. The virtual front lines move around quickly, alliances are malleable, and the geopolitical actors are connected to each other through a multiplicity of hidden agendas. Even though this method of waging war is usually attributed to states or secret services, al-Qaida-and probably the leadership of the Islamic State, too-have evidently been using it in a conscious and efficient way.

Gadahn, for example, was preoccupied with the hostility between Jews and Christians or the antagonism of Catholics and Protestants as a friction on which subversive and recruiting activities could be built. He viewed Middle Eastern Christians and Catholics in general as a susceptible group who may be opposed to Jews and Protestants enough to be more open to Islam. Therefore, he criticized the attack on the Baghdad Catholic church, claiming that it "does not help us convey the message." This, on the other hand, was difficult for their own fighters and ideologists to accept. Gadahn struck a chord that may have mitigated the expected outrage:

"How beautiful what Shaykh Usama mentioned lately -when talking about a media speech- that the strong statements that were mentioned by the ancestors were said during days of dignity and control, and therefore it is not fitting to the era of vulnerability....So it cannot be implemented on the days of weakness like our present days."

He mentioned destroying churches and "devious religious books" as an example. Yet he also felt right to discuss - probably because he could sense 
the weakness of his argument-"the animosity of the Pope and other church heads to Islam and Muslims." 33 When al-Qaida leaders fantasize about the possibility of an alliance with Catholics against Jews and Protestants, they are unaware of their limitations-probably due to their lack of knowledge regarding the Jewish-Christian roots of European culture and-largely-to their arrogance.

\section{Conclusion}

In his study on al-Qaida's media efforts, Philip Seib asserts, “Al-Qaeda has become a significant player in global politics largely because it has developed a sophisticated media strategy." 34 This body of research is intended as an analysis of that sophisticated media strategy and tactical planning, which has, in my view, received less scientific attention lately than the media products themselves. As the resources may have indicated, observing the way of thinking revealed by these documents could-especially considering the ideological and network-to-network continuity between jihadi terrorist organizations - provide valuable pointers for analysing present-day jihadi propaganda and the psychological warfare waged through media practices.

\footnotetext{
1 Ágnes Hankiss “The Legend of the Lone Wolf," Journal of Strategic Security 11, no. 2 (2018), http://dx.doi.org/10.5038/1944-0472.11.2.1668

2 Daniel Milton, Communication Breakdown: Unraveling the Islamic State's Media Efforts (West Point: Combatting Terrorism Center, 2016, IV), https://ctc.usma.edu/app/uploads/2016/10/ISMedia_Online.pdf.

3 Ali Soufan, Anatomy of Terror: From the Death of Bin Laden to the Rise of The Islamic State, (New York: W.W.Norton \& Company, Inc., 2018), 175-76.

4 Ágnes Hankiss, “Átívelő hálózatok. Az al-Kaidától az ISIS-ig.” [Overlapping networks: from al-Qa ida to ISIS] Terror és elhárítás, 2018. 7/1,

http://epa.oszk.hu/o2900/02932/o0016/pdf/EPA02932_terror_elharitas_2018_1_072099.pdf

5 CAT Centre d'analyse du terrorism: „Selon la ministre de la justice, Nicole Belloubet, 450 détenus radicalisés seront libérés avant la fin de l'année 2019”. Le Monde, 13 June 2018, https://www.lemonde.fr/les-decodeurs/article/2018/o6/13/ce-que-l-on-sait-des-450detenus-radicalises-qui-seront-liberes-d-ici-2019_5314185_4355770.html

${ }^{6}$ Jean-Pierre Stroobants, "Molenbeek, la plaque tournante belge du terrorisme islamiste." Le Monde, 16 November 2015, http://www.lemonde.fr/europe/article/2015/11/16/molenbeekla-plaque-tournante-belge-du-terrorisme-islamiste_4810617_3214.html\# (Accessed on 2018. 01. 04.)

7 Brian Fishman, Presentation at the ICT World Summit 2018, ICT.org.il

8 Ágnes Hankiss, Terrorista hálózatok. A C (Carlos)-79-es dosszié [Terrorist Networks: The C (Carlos)-79 folder]. Terror és Elhárítás, 2017. 6/4, http://epa.oszk.hu/02900/o2932/00014/pdf/EPA02932_terror_elharitas_2017_4_004022.pdf
} 
9 Daniel Milton, "Pulling Back the Curtain: An Inside Look at the Islamic State's Media Organization," CTC at West Point, 28 August 2018, Report Description, https://ctc.usma.edu/pulling-back-the-curtain-an-inside-look-at-the-islamic-states-mediaorganization/

${ }^{10}$ Liam Collins, "The Abbottabad Documents: Bin Laden's Security Measures," CTC at West Point, May 2012, Volume 5, Issue 5.

${ }^{11}$ N. Lahoud, S. Caudill, L. Collins, G. Koehler-Derrick, D. Rassler, M. Al-Ubaydi, "Letters from Abbottabad: Bin Ladin Sidelined?”, Harmony Program, CTC West Point, 3 May 2012, https://ctc.usma.edu/app/uploads/2012/05/CTC_LtrsFromAbottabad_WEB_v2.pdf ${ }_{12}$ N. Lahoud et al., "Letters from Abbottabad: Bin Ladin Sidelined?", 52.

13 Harmony Documents, SOCOM-2012-0000010

14 "Letter to Nasir al-Wuhayshi," Harmony Documents, SOCOM-2012-0oooo16, 7-8, https://ctc.usma.edu/app/uploads/2013/10/Letter-to-Nasir-al-Wuhayshi-Translation.pdf ${ }^{15}$ A. Soufan, Anatomy of Terror, 20

16 A. Soufan, Anatomy of Terror, 16

17 "Letter Regarding Al-Qa ida Strategy," Harmony Documents, SOCOM-2012-00ooo17, 6, https://ctc.usma.edu/harmony-program/letter-regarding-al-qaida-strategy-originallanguage-2/

18 "Letter from Adam Gadahn," Harmony Documents, SOCOM-2012-0ooooo4, 1, https://ctc.usma.edu/app/uploads/2013/10/Letter-from-Adam-Gadahn-Translation.pdf 19 "Letter Regarding Al-Qa ida Strategy," Harmony Documents, SOCOM-2012-0000017, 2, https://ctc.usma.edu/harmony-program/letter-regarding-al-qaida-strategy-originallanguage-2/

20 "The First Issue of Characteristics of Jihad Magazine," Harmony Documents, AFGP-2002600142, 1-36, https://ctc.usma.edu/app/uploads/2013/10/Characteristics-of-JihadMagazine-Issue-One-March-Original.pdf

${ }_{21}$ "The First Issue of Characteristics of Jihad Magazine," Harmony Documents, AFGP-2002600142, 1-36, https://ctc.usma.edu/app/uploads/2013/10/Characteristics-of-JihadMagazine-Issue-One-March-Original.pdf

22 "The First Issue of Characteristics of Jihad Magazine," Harmony Documents, AFGP-2002600142, 1-36, https://ctc.usma.edu/app/uploads/2013/10/Characteristics-of-JihadMagazine-Issue-One-March-Original.pdf

23 "Information on Abu-Malik Battalion and other reports and details," Harmony Documents, JDECB-2007-002124, 5, https://ctc.usma.edu/app/uploads/2016/09/JDECB-2007-002124Trans.pdf

24 "The framework for media functions at Salah al-Din Jurisdiction," Harmony Documents, NMEC-2007-637123, 1, https://ctc.usma.edu/app/uploads/2016/o9/NMEC-2007-637116Trans.pdf

25 Philip Seib, "The Al-Qaeda Media Machine," Military Review (May-June 2008), 76-77, https://www.hsdl.org/?view\&did=486220.

26 "Recommendations from the ISI Information Ministry on the Prince of Martyrs Project," Harmony Documents, NMEC-2007-637123,

https://ctc.usma.edu/app/uploads/2013/o9/Recommendations-from-the-ISI-InformationMinistry-on-the-Prince-of-Martyrs-Project-Translation.pdf

27 "A Letter by the Deputy Commander of Media and Recruitment Division of Jihad and Liberation Group", Harmony Documents, JDECB-2010-000854, 5, https://ctc.usma.edu/app/uploads/2014/o8/JDECB-2010-000854-Trans.pdf 28 "Letter from UBL to `Atiyatullah Al-Libi 3," Harmony Documents, SOCOM-2012ooooo15, 1-8, https://ctc.usma.edu/app/uploads/2013/10/Letter-from-UBL-to-AtiyatullahAl-Libi-3-Translation1.pdf

29 "Letter from UBL to “Atiyatullah Al-Libi 3," Harmony Documents, SOCOM-2012-0000015, 1-8, https://ctc.usma.edu/app/uploads/2013/10/Letter-from-UBL-to-Atiyatullah-Al-Libi-3Translation1.pdf

30 "Letter from Adam Gadahn," Harmony Documents, SOCOM-2012-0ooooo4, 1, https://ctc.usma.edu/app/uploads/2013/10/Letter-from-Adam-Gadahn-Translation.pdf 
$3_{1}$ "Letter from Adam Gadahn," Harmony Documents, SOCOM-2012-0ooooo4, 1, https://ctc.usma.edu/app/uploads/2013/10/Letter-from-Adam-Gadahn-Translation.pdf 32 "Letter from Adam Gadahn," Harmony Documents, SOCOM-2012-0000004, 1, https://ctc.usma.edu/app/uploads/2013/10/Letter-from-Adam-Gadahn-Translation.pdf 33 "Letter from Adam Gadahn," Harmony Documents, SOCOM-2012-0000004, 6, https://ctc.usma.edu/app/uploads/2013/10/Letter-from-Adam-Gadahn-Translation.pdf 34 Seib, “The Al-Qaeda Media Machine," 74. 